\title{
Polymorphisms of selected genes related to increased cardiovascular risk in patients with acute coronary syndromes and their relation to the severity of coronary artery disease
}

Polimorfizm wybranych genów związanych ze zwiększonym ryzykiem sercowo-naczyniowym u pacjentów z ostrymi zespołami wieńcowymi i ich wpływ na stopień nasilenia choroby wieńcowej

İbrahim Gül', Zekeriya Küçükdurmaz'1 Nihat Kalay², Hekim Karapinar'1, Mehmet Tuğrul İnanç², İbrahim Özdoğru², Ahmet Yılmaz', Namık Kemal Eryol ${ }^{2}$

${ }^{1}$ Cardiology Department, Cumhuriyet University Medical School, Sivas, Turkey

${ }^{2}$ Cardiology Department, Erciyes University Medical School, Kayseri, Turkey

Post Kardiol Interw 2012; 8, 1 (27): 25-30 DOI: $10.5114 /$ pwki.2012.27922

\begin{abstract}
Background: $\beta$-Fibrinogen 455G/A, factor V 1691G/A, 1299H/A and glycoprotein Ilb/Illa PL A1/A2 polymorphisms are tought to be related to arterial thrombotic disorders, especially coronary artery disease (CAD) and myocardial infarction (MI).

Aim: The aims of this study were to investigate the frequencies of these polymorphisms in subgroups of acute coronary syndromes (ACS) and the effects of these polymorphisms on the angiographic findings of patients with ACS.

Material and methods: The study included 35 patients (mean age 61 years) diagnosed with ACS who underwent coronary angiography. The patients with ST elevation MI comprised group I and patients without ST elevation comprised group II.

Results: The groups were not different regarding clinical properties of patients and CAD risk factors. The numbers of patients with $\beta$-fibrinogen 455A, factor V 1691A and 1299A, and glycoprotein IIb/IIla PL A2 alleles were 7 (46.7\%) and 8 (40\%), $3(20 \%)$ and 4 (20\%), $3(20 \%)$ and $3(15 \%)$, and $3(20 \%)$ and $5(25 \%)$, in groups I and II respectively $(p=0.69, p=1.0, p=0.69, p=0.72$, respectively). Angiographic findings were not related to these polymorphisms.

Conclusions: We did not find any relation among ACS subtype and angiographic severity of coronary atherosclerosis with $\beta$-fibrinogen 455G/A, factor V 1691G/A, 1299H/A and glycoprotein Ilb/IIla PL A1/A2 polymorphisms. These findings suggest that these polymorphisms have no effects on the relative magnitude of thrombus responsible for ACS or the severity of the occlusion of the coronary artery related ACS. Future studies with larger groups may reveal whether these genetic alterations have a significant impact on ACS.
\end{abstract}

Key words: acute coronary syndrome, coagulation protein, genes, polymorphism

\section{Streszczenie}

Wstęp: Polimorfizmy 455G/A $\beta$-fibrynogenu, 1691G/A i 1299H/A czynnika V oraz PL A1/A2 glikoproteiny Ilb/Illa wiążą się z powikłaniami zakrzepowymi w układzie tętniczym, zwłaszcza z chorobą wieńcową i zawałem serca.

Cel: Celem badania była ocena częstości występowania badanych polimorfizmów u pacjentów z różnymi typami ostrych zespołów wieńcowych (OZW) oraz ocena wpływu tych polimorfizmów na zmiany stwierdzane w koronarografii u pacjentów z OZW.

Materiat i metody: Badaniem objęto 35 pacjentów (średni wiek 61 lat) z rozpoznaniem OZW, u których wykonano koronarografię. Pacjenci z zawałem serca z uniesieniem odcinka ST stanowili grupę I, a pacjenci bez uniesienia odcinka ST - grupę II.

Wyniki: Nie wykazano różnic dotyczących charakterystyki klinicznej i obecności czynników ryzyka wystąpienia choroby wieńcowej pomiędzy grupami. Liczba pacjentów z allelem 455A $\beta$-fibrynogenu, 1691A i 1299A czynnika V oraz PL A2 glikoproteiny Ilb/Illa wynosita odpowiednio w grupie I i II: 7 (46,7\%) i 8 (40\%), 3 (20\%) i 4 (20\%), 3 (20\%) i 3 (15\%) oraz 3 (20\%) i 5 (25\%) (odpowiednio: $p=0,69, p=1,0, p=0,69, p=0,72)$. Zmiany stwierdzane w koronarografii nie wykazywały związku z obecnością tych polimorfizmów.

Wnioski: Nie stwierdzono żadnego związku pomiędzy typem OZW, ciężkością nasilenia zmian miażdżycowych w koronarografii a polimorfizmami 455G/A $\beta$-fibrynogenu, 1691G/A i 1299H/A czynnika V oraz PL A1/A2 glikoproteiny Ilb/Illa. Wyniki sugerują, że

Corresponding author/Adres do korespondencji:

Zekeriya Küçükdurmaz MD, Assist. Prof., Cumhuriyet Universitesi, Araștırma ve Uygulama Hastanesi Kardiyoloji Anabilim Dalı, 58140 Sivas,

Turkey, tel.: +90 533 6122444, fax: +90 346 2191155, e-mail: trimesgites@hotmail.com

Praca wpłynęła: 17.10.2011, wersja poprawiona: 9.03.2012, przyjęta do druku: 9.03.2012. 
polimorfizmy nie wpływają na względną wielkość zakrzepu powodującego OzW lub stopień zwężenia (do okluzji włącznie) tętnicy wieńcowej odpowiedzialnej za OzW. Dalsze badania obejmujące większe grupy pacjentów mogą wykazać, czy te zmiany genetyczne mają istotny wpływ na OZW.

Słowa kluczowe: ostry zespół wieńcowy, czynnik krzepnięcia, geny, polimorfizm

\section{Background}

Cardiovascular disease, especially coronary artery disease (CAD), is the primary cause of mortality and mortality worldwide. Coronary artery disease has a multifactorial pathogenesis, which involves environmental and inherited risk factors. Patients with CAD are admitted to hospital most frequently with acute coronary syndromes [1]. Acute coronary syndromes (ACS) are the most mortal clinical manifestation of CAD. A thrombus on a ruptured atherosclerotic plaque is the main cause of ACS [2].

The role of haemostatic markers as factors predisposing to thrombus formation and atherosclerosis was investigated, and several genetic mutations affecting coagulation proteins were suggested as likely inherited risk factors for CAD $[3,4]$. In this study, $\beta$-fibrinogen $455 \mathrm{G} / \mathrm{A}$, factor $\mathrm{V}$ 1691G/A, 1299H/A and glycoprotein (Gp) Ilb/IIla PL A1/A2 polymorphisms were the subjects of investigation. These polymorphisms are responsible for some alterations in the coagulation system and are proposed as risk factors for CAD, especially in younger populations or in association with traditional cardiovascular risk factors, such as smoking [5].

\section{Aim}

Therefore this study was designed to investigate the frequencies of the mentioned polymorphisms in two major groups of ACS (ST elevation and non-ST elevation), to investigate the relationship between ACS subtypes and mentioned polymorphisms, and to investigate the relation between these polymorphisms and the angiographic severity of coronary atherosclerosis.

\section{Material and methods}

The study consisted of 45 consecutive patients who were admitted to our hospital with ACS and then underwent coronary angiography (CAG). Subjects were excluded if they had a history of CAD, revascularization therapies, malignancy, bleeding diathesis or hypercoagulable state, or received medications such as aspirin, clopidogrel or warfarin which affect the coagulation system. The platelet counts and prothrombin times of patients were assessed and patients with platelet counts below $150000 / \mathrm{ml}$ or above $400000 / \mathrm{ml}$ or with an INR (international normalised ratio) higher than 1.5 were also excluded. The current study was approved by the local ethics committee and all participants gave informed consent.
The diagnoses of ACS were made according to ACC/AHA guidelines [6]. There were two groups in the study: the ST elevation (STE) group consisted of patients with ST elevation myocardial infarction (STEMI), and the non-ST elevation group (NSTE) consisted of patients with unstable angina (USAP) and non-ST elevation myocardial infarction (NSTEMI).

\section{Genetic analysis}

DNA was isolated from whole blood using standard procedures. The genotype analyses were made by polymerase chain reactions (PCR) using CVD Strip Assay (Viennalab $\mathrm{GmBH}$, Vienna, Austria). Three genotypes were determined for each gene: $G / G, G / A$ and $A / A$ for $\beta$-fibrinogen 455; G/G, G/A and A/A for factor V 1691; H/H, H/A and A/A for factor V 1299; A1/A1, A1/A2 and A2/A2 for Gp IIb/IIla $\mathrm{PL}$ To compare the frequencies of polymorphisms between the groups, the mutant allele was used in statistical analyses. The mutant allele was A for $\beta$-fibrinogen $455 \mathrm{G} / \mathrm{A}$, factor $V 1691 \mathrm{G} / \mathrm{A}$ and $1299 \mathrm{H} / \mathrm{A}$ polymorphisms and A2 for Gp Ilb/IIla PL A1/A2 polymorphism.

Selective coronary angiography was performed with the standard technique with the Integris H 5000 model monoplane cardiac angiography device (Philips Medical Systems Nederland). The angiograms recorded on CD media were evaluated by two experienced observers via Image View DICOM Player computer program. All atherosclerotic lesions were investigated and the following angiographic parameters were calculated to define the severity of coronary atherosclerosis in patients: the number of diseased vessels with stenosis higher than $10 \%$ (DV $\geq \% 10$ ), the number of diseased vessels with stenosis higher than $50 \%$ (DV $\geq \% 50$ ), and total number of atherosclerotic lesions with a lumen narrowing equal to or higher than $70 \%$ (TLC, total lesion count). Furthermore, the atherosclerotic lesions were classified according to the ACC/AHA lesion classifications and numbers of type A, B and C lesions were calculated [7]. Also Gensi$\mathrm{ni}$ and Extent scores were calculated to establish the severity of coronary atherosclerosis as reported previously [8-10].

\section{Statistical analysis}

Student $t$ and Mann-Whitney $U$ tests were used to compare means and $\chi^{2}$ tests to compare proportions. All probability values were two-sided and a $p$ value below 0.05 was accepted as significant. SPSS Version 15.0 for Win- 
dows (SPSS Inc., Chicago, IL, USA) was used to perform all statistical calculations.

\section{Results}

Forty-five patients were included preliminarily in the study, 23 in the STE group and 22 in the NSTE group, but DNA of 3 patients from the STE group and 7 from the NSTE group could not be assessed. Data of a total of 35 patients were entered in the statistical analyses. The mean age was $61.65 \pm 11.5$ years. The NSTE group consisted of 15 patients (9 males, 6 females) and the STE group consisted of 20 (13 males, 7 females). The diagnosis of patients in the NSTE group was NSTEMI in 4 and USAP in 11; in the STE group, anterior $\mathrm{MI}$ in 13 and inferior $\mathrm{MI}$ in 7.

The baseline characteristics were not different between groups (Table 1). The angiographic parameters, Gensini and extent scores were also not significantly different (Table 2). The proportions of patients with mutant alleles were similar in the two groups for all polymorphisms (Table 3).

Fifteen patients (42.8\%) from all 35 had a $\beta$-fibrinogen $455 \mathrm{~A}$ allele. The angiographic parameters, Gensini and extent scores were not different among the patients with a 455A allele and patients without a 455A allele. The same comparisons were made for the other three polymorphisms, but the differences were not statistically significant (Table 4).

\section{Discussion}

Every year approximately 1.7 million ACS patients are admitted to hospitals in the USA. Of those, only one-quarter present with acute STEMI; three-quarters (approximately 1.4 million patients) present with USAP or NSTEMI [11]. Angiographic studies showed that luminal obstructions by thrombus in culprit coronary arteries are significantly different according to the presence of ST segment elevation. Acute STEMI is most commonly caused by acute

Table 2. Comparison of angiographic findings of patients in group I and II

Tabela 2. Porównanie wyników badania angiograficznego u pacjentów z grupy I i II

\begin{tabular}{lccc} 
Parameter & $\begin{array}{c}\text { Group I } \\
(n=15)\end{array}$ & $\begin{array}{c}\text { Group II } \\
(n=20)\end{array}$ & Value of $p$ \\
\hline Vessel diameter $[\mathrm{mm}]$ & $2.98 \pm 0.4$ & $3.20 \pm 0.8$ & 0.32 \\
\hline DV $\geq 10 \%$ & $2.13 \pm 1.0$ & $2.30 \pm 0.73$ & 0.82 \\
\hline DV $\geq 50 \%$ & $1.53 \pm 1.18$ & $1.60 \pm 0.8$ & 0.84 \\
\hline Total lesion count & $2.20 \pm 2.1$ & $1.80 \pm 0.9$ & 0.46 \\
\hline Type A lesion count & $0.33 \pm 0.6$ & $0.31 \pm 0.7$ & 0.72 \\
\hline Type B lesion count & $1.13 \pm 1.7$ & $1.15 \pm 0.6$ & 0.16 \\
\hline Type C lesion count & $0.86 \pm 0.9$ & $0.42 \pm 0.5$ & 0.21 \\
\hline Gensini score & $6.66 \pm 5.1$ & $6.65 \pm 2.7$ & 0.99 \\
\hline Extent score & $19.73 \pm 19.1$ & $13.20 \pm 6.5$ & 0.16
\end{tabular}

Results shown as mean $\pm S D$. DV - diseased vessels
Table 1. Comparison of baseline characteristics of patients in group I and II

Tabela 1. Porównanie charakterystyki podstawowej pacjentów z grupy I i ll

\begin{tabular}{lccc} 
Parameter & $\begin{array}{c}\text { Group I } \\
(n=15)\end{array}$ & $\begin{array}{c}\text { Group II } \\
(n=20)\end{array}$ & Value of $p$ \\
\hline Age [years] & $62.66 \pm 10.5$ & $60.90 \pm 12.5$ & 0.64 \\
\hline Gender (male/female), $n$ & $9 / 6$ & $13 / 7$ & 1.00 \\
\hline Diabetes mellitus [\%] & 26.6 & 15 & 0.39 \\
\hline Hypertension [\%] & 33.3 & 30 & 0.83 \\
\hline Smoking [\%] & 46.6 & 75 & 0.08 \\
\hline Family history & 33.3 & 25 & 0.58 \\
\hline Total cholesterol [mg/dl] & $171.93 \pm 32.3$ & $164.20 \pm 48.9$ & 0.65 \\
\hline LDL cholesterol [mg/dl] & $104.06 \pm 25.9$ & $103.85 \pm 35.8$ & 0.81 \\
\hline HDL cholesterol [mg/dl] & $48.73 \pm 11.3$ & $43.25 \pm 12.1$ & 0.30
\end{tabular}

Results shown as mean $\pm S D$ or percentage

total thrombotic occlusion of a coronary artery, whereas USAP/NSTEMI is usually associated with severe coronary obstruction but no total occlusion of the culprit coronary artery [12-15]. The question why the thrombus occludes the culprit artery totally in some patients and not totally in others is not clearly answered. This may be partially explained by the fact that former studies that investigated the formation of thrombi in acute $\mathrm{MI}$ used the old $\mathrm{MI}$ classification: $\mathrm{Q}$ and non-Q [16]. The atherosclerotic plaques that are associated with thrombosis and a total occlusion, located in infarct-related vessels, are generally more complex and irregular than those in vessels not associated with STEMI. Coronary arterial thrombi responsible for STEMI are approximately $1 \mathrm{~cm}$ in length in most cases, adhere to the luminal surface of an artery, and are composed of platelets,

Table 3. Comparison of genetic findings of patients in group I and II

Tabela 3. Porównanie wyników badań genetycznych u pacjentów z grupy / i /l

\begin{tabular}{|c|c|c|c|}
\hline & $\begin{array}{l}\text { Group I } \\
(n=15)\end{array}$ & $\begin{array}{l}\text { Group II } \\
(n=20)\end{array}$ & Value of $p$ \\
\hline \multicolumn{4}{|l|}{$\beta$-Fibrinogen 455} \\
\hline $\mathrm{G} / \mathrm{G}, n(\%)$ & $8(53.3)$ & $12(60)$ & \\
\hline $\mathrm{G} / \mathrm{A}+\mathrm{A} / \mathrm{A}, n(\%)$ & $7(46.7)$ & $8(40)$ & 0.69 \\
\hline \multicolumn{4}{|l|}{ Factor V 1691} \\
\hline $\mathrm{G} / \mathrm{G}, n(\%)$ & $12(80)$ & $16(80)$ & \\
\hline $\mathrm{G} / \mathrm{A}, n(\%)$ & $3(20)$ & $4(20)$ & 1.00 \\
\hline \multicolumn{4}{|l|}{ Factor V 1299} \\
\hline $\mathrm{H} / \mathrm{H}, n(\%)$ & $12(80)$ & $17(85)$ & \\
\hline $\mathrm{H} / \mathrm{A}, n(\%)$ & $3(20)$ & $3(15)$ & 0.69 \\
\hline \multicolumn{4}{|l|}{ Glycoprotein IIb/IIla PL } \\
\hline $\mathrm{A} 1 / \mathrm{A} 1, n(\%)$ & $12(80)$ & $15(75)$ & \\
\hline $\mathrm{A} 1 / \mathrm{A} 2+\mathrm{A} 2 / \mathrm{A} 2, n(\%)$ & $3(20)$ & $5(25)$ & 0.72 \\
\hline
\end{tabular}


Table 4. Comparison of angiographic findings of patients grouped for $\beta$-fibrinogen 455G/A, $\beta$-fibrinogen 1691G/A and $\beta$-fibrinogen $1299 \mathrm{H} / \mathrm{A}$ polymorphisms

Tabela 4. Porównanie wyników koronarografii u pacjentów podzielonych na grupy pod względem występowania polimorfizmów 455G/A $\beta$-fibrynogenu, 1691G/A $\beta$-fibrynogenu i 1299H/A $\beta$-fibrynogenu

\begin{tabular}{|c|c|c|c|c|c|c|c|c|c|c|c|c|}
\hline & \multicolumn{3}{|c|}{$\begin{array}{c}\boldsymbol{\beta} \text {-Fibrinogen } 455 \mathrm{G} / \mathrm{A} \\
\text { polymorphism }\end{array}$} & \multicolumn{3}{|c|}{$\begin{array}{l}\text { Factor V 1691G/A } \\
\text { polymorphism }\end{array}$} & \multicolumn{3}{|c|}{$\begin{array}{c}\text { Factor V 1299H/A } \\
\text { polymorphism }\end{array}$} & \multicolumn{3}{|c|}{$\begin{array}{l}\text { Gp PL A1/A2 } \\
\text { polymorphism }\end{array}$} \\
\hline & $\begin{array}{l}\text { Patients } \\
\text { without } \\
455 \mathrm{~A} \\
\text { allele } \\
(n=20)\end{array}$ & $\begin{array}{l}\text { Patients } \\
\text { with } \\
455 \mathrm{~A} \\
\text { allele } \\
(n=15)\end{array}$ & $\begin{array}{l}\text { Value } \\
\text { of } p\end{array}$ & $\begin{array}{c}\text { Patients } \\
\text { without } \\
1691 \mathrm{~A} \\
\text { allele } \\
(n=28)\end{array}$ & $\begin{array}{l}\text { Patients } \\
\text { with } \\
1691 \mathrm{~A} \\
\text { allele } \\
(n=7)\end{array}$ & $\begin{array}{l}\text { Value } \\
\text { of } p\end{array}$ & $\begin{array}{c}\text { Patients } \\
\text { without } \\
1299 A \\
\text { allele } \\
(n=29)\end{array}$ & $\begin{array}{l}\text { Patients } \\
\text { with } \\
1299 A \\
\text { allele } \\
(n=6)\end{array}$ & $\begin{array}{l}\text { Value } \\
\text { of } p\end{array}$ & $\begin{array}{c}\text { Patients } \\
\text { without } \\
\text { PL A2 } \\
\text { allele } \\
(n=27)\end{array}$ & $\begin{array}{l}\text { Patients } \\
\text { with } \\
\text { PL A2 } \\
\text { allele } \\
(n=8)\end{array}$ & $\begin{array}{l}\text { Value } \\
\text { of } p\end{array}$ \\
\hline $\mathrm{DV} \geq 10 \%$ & $2.05 \pm 0.9$ & $2.46 \pm 0.63$ & 0.29 & $2.28 \pm 0.8$ & $2.00 \pm 0.8$ & 0.33 & $2.13 \pm 0.9$ & $2.66 \pm 0.5$ & 0.20 & $2.14 \pm 0.8$ & $2.50 \pm 0.9$ & 0.23 \\
\hline DV $\geq 50 \%$ & $1.60 \pm 0.9$ & $1.53 \pm 0.9$ & 0.83 & $1.67 \pm 1.0$ & $1.14 \pm 0.7$ & 0.20 & $1.55 \pm 1.0$ & $1.66 \pm 0.8$ & 0.79 & $1.48 \pm 0.9$ & $1.87 \pm 1.1$ & 0.32 \\
\hline $\begin{array}{l}\text { Total lesion } \\
\text { count }\end{array}$ & $2.10 \pm 1.7$ & $1.80 \pm 1.3$ & 0.69 & $2.10 \pm 1.7$ & $1.80 \pm 1.3$ & 0.69 & $2.00 \pm 1.6$ & $1.83 \pm 0.7$ & 0.81 & $1.96 \pm 1.6$ & $2.00 \pm 1.1$ & 0.95 \\
\hline $\begin{array}{l}\text { Type A } \\
\text { lesion count }\end{array}$ & $0.25 \pm 0.7$ & $0.42 \pm 0.6$ & 0.19 & $0.37 \pm 0.7$ & $0.14 \pm 0.3$ & 0.49 & $0.35 \pm 0.7$ & $0.16 \pm 0.4$ & 0.62 & $0.30 \pm 0.6$ & $0.37 \pm 0.7$ & 0.84 \\
\hline $\begin{array}{l}\text { Type B } \\
\text { lesion count }\end{array}$ & $1.25 \pm 1.5$ & $1.00 \pm 0.6$ & 0.92 & $1.18 \pm 1.3$ & $1.00 \pm 0.5$ & 0.92 & $1.21 \pm 1.3$ & $0.83 \pm 0.7$ & 0.59 & $1.23 \pm 1.3$ & $0.87 \pm 0.8$ & 0.61 \\
\hline $\begin{array}{l}\text { Type C } \\
\text { lesion count }\end{array}$ & $0.65 \pm 0.8$ & $0.57 \pm 0.7$ & 0.78 & $0.70 \pm 0.8$ & $0.28 \pm 0.4$ & 0.21 & $0.57 \pm 0.8$ & $0.83 \pm 0.7$ & 0.32 & $0.57 \pm 0.7$ & $0.75 \pm 1.0$ & 0.80 \\
\hline $\begin{array}{l}\text { Gensini } \\
\text { score }\end{array}$ & $6.70 \pm 3.9$ & $6.60 \pm 3.9$ & 0.90 & $7.14 \pm 4.7$ & $4.71 \pm 2.4$ & 0.12 & $6.75 \pm 4.2$ & $6.16 \pm 1.7$ & 0.87 & $6.44 \pm 3.9$ & $7.37 \pm 3.8$ & 0.44 \\
\hline $\begin{array}{l}\text { Extent } \\
\text { score }\end{array}$ & $15.00 \pm 10.9$ & $17.33 \pm 16.7$ & 0.93 & $17.35 \pm 14.5$ & $10.57 \pm 6.8$ & 0.26 & $16.41 \pm 14.8$ & $14.00 \pm 3.3$ & 0.70 & $16.33 \pm 14.7$ & $14.87 \pm 8.9$ & 0.72 \\
\hline
\end{tabular}

Results shown as mean $\pm S D$. DV - diseased vessels

fibrin, erythrocytes and leukocytes [17]. Observational data suggest that NSTEMI is seen more commonly in elderly patients and patients with a prior MI.

This study showed that the frequencies of the $\beta$-fibrinogen 455G/A, factor V 1691G/A, 1299H/A and Gp IIb/IIla $\mathrm{PL}$ A1/A2 polymorphisms were not different between two major groups of ACS. These findings suggest that these polymorphisms have no effects on the relative magnitude of thrombus responsible for ACS or the severity of occlusion of the coronary artery related ACS.

Many prospective studies have demonstrated a relationship between fibrinogen levels and thrombotic arterial diseases such as $\mathrm{MI}$ and ischemic stroke [18-20]. The AA genotype in $455 \mathrm{G} / \mathrm{A}$ polymorphism on the gene encoding the $\beta$ chain of fibrinogen is associated with higher fibrinogen levels. The studies investigating the relationship between the $455 \mathrm{~A}$ allele and $\mathrm{MI}$ reported conflicting results $[5,21]$. There are previously no data about the frequencies of $\beta$-fibrinogen $455 \mathrm{G} / \mathrm{A}$ polymorphism in subgroups of ACS, similarly for the other three polymorphisms: factor $V$ 1691G/A, 1299H/A and Gp IIb/IIla PL A1/A2. This study demonstrates for the first time the frequencies of these polymorphisms in subgroups of ACS. A meta-analysis investigating the relation between $\mathrm{Ml}$ and multiple genetic risk factors found that the $455 \mathrm{~A}$ allele is associated with lower incidence of $\mathrm{MI}$ [22]. So the relation between CAD and $\beta$-fibrinogen 455G/A polymorphism is not clear yet.

Factor V 1691G/A (or Leiden mutation) and 1299H/A polymorphisms are responsible for active protein $\mathrm{C}$ resist- ance: a hypercoagulable state [23-26]. Two meta-analyses showed that $\mathrm{MI}$ risk is increased 1.3 fold in patients carrying the 1691A allele [27]. The elevation of the risk did not reach statistical significance in another meta-analysis [22]. Three studies reported that the frequency of the $1691 \mathrm{~A}$ allele was higher in patients who experienced an acute MI without coronary atherosclerosis [27-29]. The patients carrying factor $V 1299 \mathrm{~A}$ allele had no higher risk for $\mathrm{MI}$ in a study, but the risk of $\mathrm{MI}$ increased 4.4 fold in association with smoking compared to non-smokers [30]. There are no data reporting the frequencies of factor $\mathrm{V} 1691 \mathrm{G} / \mathrm{A}$ and $1299 \mathrm{H} / \mathrm{A}$ polymorphisms in the two groups of ACS.

Glycoprotein IIb/IIla is the primary receptor on the surface of platelets for fibrinogen binding during haemostasis. The sensitivity of platelets to aggregation is increased in patients with PL A2 allele in Gp PL A1/A2 polymorphism on the gene encoding these receptor proteins [31]. Some of the studies investigating the relation between PL A2 allele and arterial thrombosis reported positive results [3234]. A study performed with patients with $\mathrm{MI}$ at younger ages reported that the PL A2 allele increased the risk of $\mathrm{MI}$ 1.8 fold and the elevation of risk was 13.7 fold in association with smoking [35]. Similarly, there are no data reporting the frequency of Gp PL A1/A2 polymorphism in the two groups of ACS.

The 455A allele in beta fibrinogen $455 \mathrm{G} / \mathrm{A}$ polymorphism has been shown to increase the progression of atherosclerotic plaques [36]. Some clinical properties such as age, gender and diabetes are associated with more severe 
atherosclerosis. The present study found no relation between the angiographic severity of coronary atherosclerosis and $\beta$-fibrinogen 455G/A, factor $V 1691 \mathrm{G} / \mathrm{A}$, 1299H/A and Gp Ilb/Illa PL A1/A2 polymorphisms.

\section{Limitation}

Because of the relatively small population, multivariate analyses could not be performed in this study.

\section{Conclusions}

We were not able to find any evidence for associating ACS subtype and angiographic severity of coronary atherosclerosis with $\beta$-fibrinogen $455 \mathrm{G} / \mathrm{A}$, factor $\mathrm{V}$ 1691G/A, $1299 \mathrm{H} / \mathrm{A}$ and Gp IIb/IIla PL A1/A2 polymorphisms. These findings suggest that these polymorphisms have no effects on the relative magnitude of thrombus responsible for ACS or the severity of the occlusion of the coronary artery related ACS. Future studies with larger groups may reveal whether these genetic alterations have a significant impact on ACS.

\section{References}

1. Chockalingam A, Balaguer-Vintro I, Achutti A, et al. The World Heart Federation's white book: Impending global pandemic of cardiovascular diseases: challenges and opportunities for the prevention and control of cardiovascular diseases in developing countries and economies in transition. Can J Cardiol 2000; 16: 231-235.

2. Falk E, Shah PK, Fuster V. Coronary plaque disruption. Circulation 1995; 92: 657-671.

3. Voetsch B, Loscalzo J. Genetic determinants of arterial thrombosis. Arterioscler Thromb Vasc Biol 2004; 24: 216-229.

4. Nordlie MA, Wold LE, Kloner RA. Genetic contributors toward increased risk for ischemic heart disease. J Mol Cell Cardiol 2005; 39: 667-679.

5. Endler G, Mannhalter C. Polymorphisms in coagulation factor genes and their impact on arterial and venous thrombosis. Clin Chim Acta 2003; 330: 31-55.

6. Braunwald E, Antman EM, Beasley JW, et al. ACC/AHA guidelines for the management of patients with unstable angina and nonST-segment elevation myocardial infarction: executive summary and recommendations. A report of the American College of Cardiology/American Heart Association task force on practice guidelines (committee on the management of patients with unstable angina). Circulation 2000; 102: 1193-1209.

7. Zaacks SM, Allen JE, Calvin JE, et al. Value of the American College of Cardiology/American Heart Association stenosis morphology classification for coronary interventions in the late 1990s. Am J Cardiol 1998; 82: 43-49.

8. Gensini GG, Kelly AE. Incidence and progression of coronary artery disease. An angiographic correlation in 1,263 patients. Arch Intern Med 1972; 129: 814-823.

9. Gensini GG. A more meaningful scoring system for determining the severity of coronary heart disease. Am J Cardiol 1983; 51: 606-607.

10. Sullivan DR, Marwick TH, Freedman SB. A new method of scoring coronary angiograms to reflect extent of coronary atherosclerosis and improve correlation with major risk factors. Am Heart J 1990; 119: 1262-12627.

11. American Heart Association: 2004 Heart and Stroke Statistical Update. Available from: URL: www.americanheart.org.

12. DeWood MA, Spores J, Notske R, et al. Prevalence of total coronary occlusion during the early hours of transmural myocardial infarction. N Engl J Med 1980; 303: 897-902.

13. TIMI Study Group. The Thrombolysis in Myocardial Infarction (TIMI) trial. Phase I findings. N Engl J Med 1985; 312: 932-936.

14. DeWood MA, Stifter WF, Simpson CS, et al. Coronary arteriographic findings soon after non-Q-wave myocardial infarction. N Engl J Med 1986; 315: 414-423.

15. TIMI IIIA Investigastors. Early effects of tissue-type plasminogen activator added to conventional therapy on the culprit lesion in patients presenting with ischemic cardiac pain at rest. Results of the Thrombolysis in Myocardial Ischemia (TIMI IIIA) trial. Circulation 1993; 87: 38-52.

16. Rentrop KP. Thrombi in acute coronary syndromes: revisted and revised. Circulation 2000; 101: 1619-1626.

17. Falk E. Coronary thrombosis: pathogenesis and clinical manifestations. Am J Cardiol 1991; 68: 28B-35B.

18. Meade TW, Mellows S, Brozovic M, et al. Haemostatic function and ischaemic heart disease: principal results of the Northwick Park Heart Study. Lancet 1986; 2: 533-537.

19. Heinrich J, Balleisen L, Schulte H, et al. Fibrinogen and factor VII in the prediction of coronary risk: results from the PROCAM study in healthy men. Arterioscler Thromb 1994; 14: 54-59.

20. Scarabin PY, Arveiler D, Amouyel P, et al. Plasma fibrinogen explains much of the difference in risk of coronary heart disease between France and Northern Ireland. The PRIME study. Atherosclerosis 2003; 166: 103-109.

21. Behague I, Poirier O, Nicaud V, et al. Beta fibrinogen gene polymorphisms are associated with plasma fibrinogen and coronary artery disease in patients with myocardial infarction: The ECTIM Study. Etude Cas-Temoins sur l'Infarctus du Myocarde. Circulation 1996; 93: 440-449.

22. Boekholdt SM, Bijsterveld NR, Moons AH, et al. Genetic variation in coagulation and fibrinolytic proteins and their relation with acute myocardial infarction: a systematic review. Circulation 2001; 104: 3063-3068.

23. Folsom AR, Cushman M, Tsai MY, et al. A prospective study of venous thromboembolism in relation to factor $\mathrm{V}$ Leiden and related factors. Blood 2002; 99: 2720-2725.

24. Lunghi B, lacoviello L, Gemmati D, et al. Detection of new polymorphic markers in the factor $V$ gene: association with factor $\checkmark$ levels in plasma. Thromb Haemost 1996; 75: 45-48.

25. Bernardi F, Faioni EM, Castoldi E, et al. A factor $V$ genetic component differing from factor $V$ R506Q contributes to the activated protein C resistance phenotype. Blood 1997; 90 : 1552-1557.

26. Juul K, Tybjaerg-Hansen A, Steffensen R, et al. Factor V Leiden: the Copenhagen City Heart Study and 2 meta-analyses. Blood 2002; 100: 3-10.

27. Van de Water NS, French JK, Lund M, et al. Prevalence of factor V Leiden and prothrombin variant G20210A in patients age $<50$ years with no significant stenoses at angiography three to four weeks after myocardial infarction. J Am Coll Cardiol 2000; 36: 717-722.

28. Lande G, Dantec V, Trossaërt M, et al. Do inherited prothrombotic factors have a role in myocardial infarction with normal coronary arteriogram? J Intern Med 1998; 244: 543-544. 
29. Mansourati J, Da Costa A, Munier S, et al. Prevalence of factor V Leiden in patients with myocardial infarction and normal coronary angiography. Thromb Haemost 2000; 83: 822-825.

30. Doggen CJ, de Visser MC, Vos HL, et al. The HR2 haplotype of factor $\mathrm{V}$ is not associated with the risk of myocardial infarction. Thromb Haemost 2000; 84: 815-818.

31. Honda S, Honda Y, Bauer B, et al. The impact of three-dimensional structure on the expression of PIA alloantigens on human integrin beta 3. Blood 1995; 86: 234-242.

32. Monkovic DD, Tracy PB. Activation of human factor $\mathrm{V}$ by factor $\mathrm{Xa}$ and thrombin. Biochemistry 1990; 29: 1118-1128.

33. Kalafatis M, Rand MD, Mann KG. The mechanism of inactivation of human factor $\mathrm{V}$ and human factor $\mathrm{Va}$ by activated protein $\mathrm{C}$. J Biol Chem 1994; 269: 31869-31880.

34. Dahlbäck B, Carlsson M, Svensson PJ. Familial thrombophilia due to a previously unrecognized mechanism characterized by poor anticoagulant response to activated protein C: prediction of a cofactor to activated protein C. Proc Natl Acad Sci USA 1993; 90: 1004-1008.

35. Ardissino D, Mannucci PM, Merlini PA, et al. Prothrombotic genetic risk factors in young survivors of myocardial infarction. Blood 1999; 94: 46-51.

36. De Maat MP, Kastelein JJ, Jukema JW, et al. -455G/A polymorphism of the beta-fibrinogen gene is associated with the progression of coronary atherosclerosis in symptomatic men: proposed role for an acute-phase reaction pattern of fibrinogen. REGRESS group. Arterioscler Thromb Vasc Biol 1998; 18: 265-271. 